\title{
REGRESSION FORMULAS FOR THE ESTIMATION OF ENGINE TOTAL POWER FOR TANKERS, CONTAINER SHIPS AND BULK CARRIERS ON THE BASIS OF CARGO CAPACITY AND DESIGN SPEED
}

\author{
Tomasz Cepowski \\ Maritime University of Szczecin, Poland
}

\begin{abstract}
This article presents regression formulas for the preliminary design of tankers, bulk carriers and container vessels, based on the data of ships built from 2000 to 2018. The formulas could have practical application for the estimation of total engine power by using ship's deadweight or TEU capacity and speed.

The regressions presented in this article are based on the most recent data and were developed for individual sub-types of tankers, bulk carriers and container ships. The presented regressions comply with trends found in the literature and offer greater accuracy for characteristics of new-built ships.
\end{abstract}

Keywords: preliminary design,total power,regression,bulk carrier,tanker,container vessel

\section{INTRODUCTION}

Ship designing is a multistage process which proceeds through preliminary, contract and detailed design stage. At the preliminary design stage major design issues such as the initial body lines, general arrangement and propulsion system are conceptualized. This early design phase consists of parametric and geometric design periods.

The main purpose of parametric design is, among others, to select main ship dimensions and estimate main propulsion and powering parameters.

As noted by Papanikolaou [9] an exact estimate of the required propulsion power for achieving design speed is not required at the preliminary design stage. This design problem can be solved by the selection of propeller and rudder in relation to other hydrodynamic ship characteristics. Papanikolaou argues that at the preliminary design, an appraisal of design power is needed to estimate:

- total ship weight, including weight of machinery and propulsion system installation,

- the required volume of engine room,

- ship fuel consumption and fuel weight.
Total ship power may also be used to pre-estimate the building price of the ship, which includes, among others, ship propulsion system parameters.

Celik et al. [1] argued that ship engine power is required to estimate tanker engine weight and cost at the preliminary design stage. Schneekluth and Bertram [12] noted that weight of engine foundation, engine plant and gearbox, as well as other engine weights such as pumps, pipes, sound absorbers and others are functions of propulsion power.

Lin and Shaw [7] suggested that container ship propulsion power is required to estimate stern frame, rudder, power generator, propeller and shaft weight and finally the total cost.

As noted by Papanikolaou [9] the following methods are commonly used for main engine power approximation at the preliminary design stage:

- geometrically similar ship methods based on the British Admiralty coefficient $\mathrm{C}_{\mathrm{N}}$.

$$
D_{N}=\frac{D^{2} / V^{3}}{P}
$$

where:

$\mathrm{C}_{\mathrm{N}}$ - coefficient, $\mathrm{V}$ - speed, $\mathrm{P}$ - installed power 
- use of technical diagrams, for example MAN B\&W Diesel diagrams [8]

Computational multi-criteria optimization methods are often used for preliminary design. To apply such methods simple mathematic equations mapping the design characteristic relationships are required. For this purpose, the geometrically similar ship methods and technical diagrams could have limited application for a main engine total power estimation. In this case a set of regression equations based on ship databases may be more practical.

The number of scientific publications dealing with propulsion power estimation at the preliminary design stage is rather small. Historically, one of the first set of regression analyses was presented by Piko [10] in 1980. Characteristics such as length, breadth, draught, gross and net registered ton capacities, as well as power and speed have been regressed each against deadweight and speed. The Lloyd's Register of Shipping database including 10334 ships was used in the publication. The main disadvantage of this form of study is the outdated nature of the database.

Żelazny [15] presented regression equations to estimate the propulsion power for container ships, tankers and bulk carriers. But the regressions were developed by using a relatively small database which only included 41 bulk carriers, 53 container ships and 32 tankers, moreover, the author did not take into account ship capacity parameters.

Ekinci et al. [3], through different computational intelligence techniques, determined principal parameters of contemporary oil/chemical tankers, also including main engine power. These authors took only into account length between perpendiculars instead of using a deadweight to engine power assessment. In the study, data from $114 \mathrm{oil} / \mathrm{chemical}$ tankers obtained from the website of Turkish Shipbuilders Association, were used. The tankers had lengths from 53 to182 m. A Levenberg-Marquardt Neural Network was applied to estimate engine total power. A problem in this method is that the mathematical models of neural networks are extremely complicated and the network presented in Ekinci paper can only be used applying computer techniques.
The engine power technical diagrams developed by engine manufacturers are often used for design analysis at the early design stage. An example propulsion power diagram published by MAN [8] is shown in Fig. 1. A drawback of this method is that the technical diagrams include nominal values and require corrections through sea trial data.

Besides the above design issues, engine power has been used to calculate the EEDI ( Energy Efficiency Design Index ). The EEDI was implemented as an amendment to the MARPOL Annex VI for new ships and aimed to use the most energy efficient and low - polluting equipment and engines. The EEDI index is used to measure $\mathrm{CO}^{2}$ emission from ships. Hence, propulsion power design methods are vitally important for this purpose as the main ship power may be used to estimate the EEDI index and also energy consumption in shipbuilding and shipping industry as a whole. Key ship characteristics optimization with regard to energy efficiency is the most effective method at the preliminary design stage.

\section{THE AIM OF RESEARCH}

The main aim of this research was to develop a set of regression formulas for such ships as tankers, bulk carriers and container ships and their sub-types.

In the parametric design phase, the key design characteristics are determined based on the most important functions of the ship. Chadzynski and Papanikolau [2,9] categorized ship types by key design characteristics, as follows:

- deadweight carriers where deadweight capacity is a decisive design characteristic; tankers and bulk carriers are typical representatives of this ship category,

- volume carriers where the most significant design characteristic is hold volume capacity; RO-RO cargo ships, car carriers, container vessels are typical for this category.

This shows that deadweight capacity may be a key design parameter for tankers and bulk carriers, and TEU container

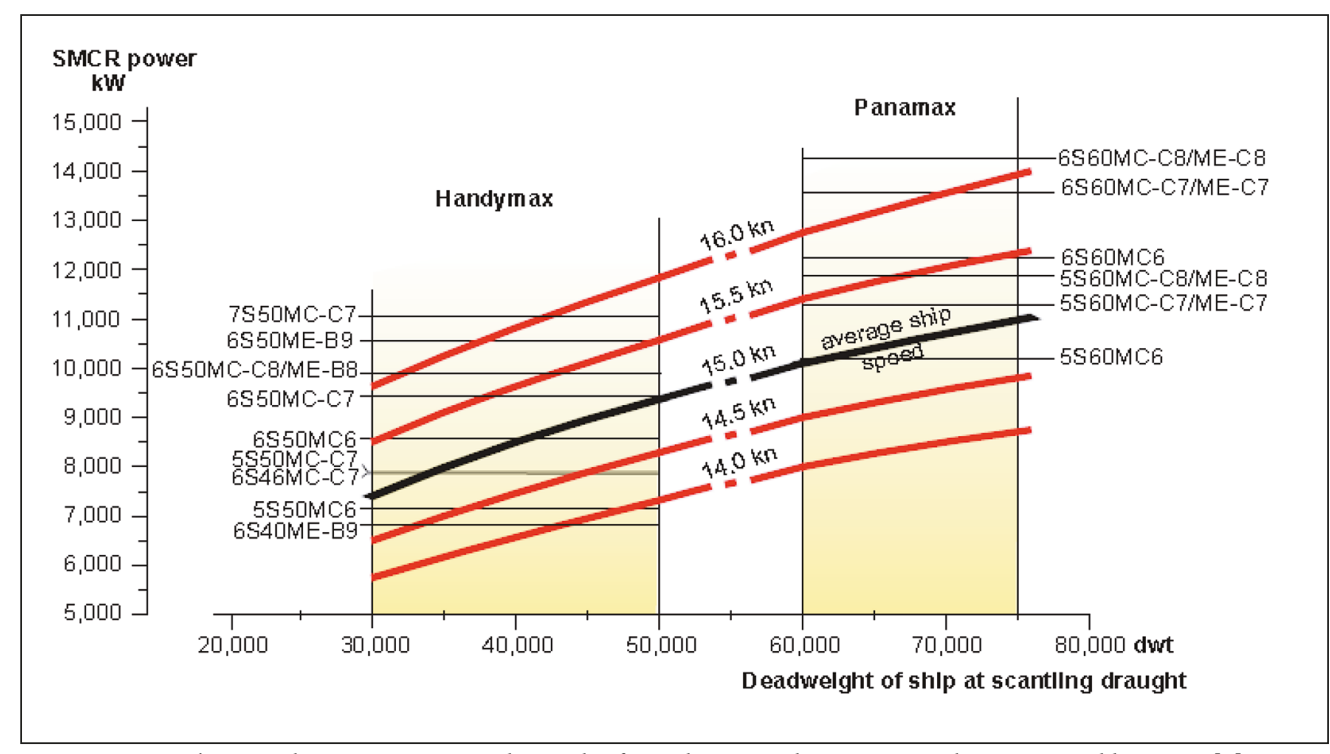

Fig. 1. The propulsion SMRC power demands of Handymax and Panamax tankers presented by MAN [8] 
capacity is a key design parameter for container ships. Chądzynski, Papanikolaou, and Watson $[2,9,14]$ argued that key design characteristics required to estimate the total power of ship main engines are deadweight or TEU capacity and design speed.

Therefore, in this study the above mentioned ship design parameters were taken into account and selected as independent variables for the estimation of main engine power, namely :

- maximum possible deadweight tonnage which corresponds to fully loaded deadweight at full summer saltwater draught (normally of $1,025 \mathrm{t} / \mathrm{m}^{3}$ density), for tankers and bulk carriers,

- a maximum number of TEU containers that could be carried by a container ship,

- design speed of a tanker, bulk carrier and container ship.

Conversely, in this study the engine power is represented by Maximum Continuous Rating (MCR). MCR is the maximum power output of engine that can be produced while running continuously at safe limits and conditions.

Therefore, the main aim of this research was to develop a set of regression formulas to estimate Maximum Continuous Rating MCR, based on the deadweight DWT or TEU capacity, as well as the design speed V:

where:

$$
\mathrm{MCR}=\mathrm{f}(\mathrm{DWT} / \mathrm{TEU}, \mathrm{V})
$$

MCR - main engine total power,

DWT - deadweight capacity,

TEU - number of containers,

$\mathrm{V}$ - design speed,

$\mathrm{f}$ - a function (design formula) to calculate main engine power.

The regression functions were developed in two ways:

- for all sub-types of tankers, bulk carriers and container ships,

- for each individual ship sub-type such as:

- Handysize, Handymax, Panamax, Aframax, Suezmax and VLCC tanker type,
- Handysize, Handymax, Panamax, Capesize, Large Capesize and VLBC bulk carrier type,

- Small Feeder, Feeder, Panamax, Post Panamax and ULCS container ship type.

The source of data used in this study was Sea-web Ships 2018 [5]. This database consists of the technical characteristics of over 200000 ships and is considered an up-to-date document of the world fleet.

From this database, technical data dealing with the recent tankers, bulk carriers and container vessels built in the years from 2000 to 2018 , were used in this research.

When using a regression method the implemented data should be of the utmost quality and clearly representative. Bad quality data lead to incorrect statistical analysis and regression coefficient values. The Sea-web Ships database contains a data set of all ships, including sister ships which have identical or similar characteristics. In this study, the ship database was fully verified. Tanker sample sizes which remained after the verification are presented in Fig 2 . The total sample sizes were as follows:

- 1710 tankers,

- 1248 bulk carriers,

- 442 container ships.

In this study, tankers were the largest group, the smallest container ships. As shown in Fig. 2 :

- The Handysize sub-type dominated the tanker group,

- The Capesize sub-type dominated the bulk carrier group

- The Feeder sub-type is the most common class in the container vessel group.

In contrast, the number of Panamax tankers, Large Capesize and VLBC bulk carriers, as well as ULCV container ships is the lowest in the ship database. The range and mean values of total engine power, deadweight, TEU capacity and design speed for particular types of ships are shown in Tab. 1-3. It is interesting that as tanker, bulk carrier and container ship capacity increased, average design speed also generally increased. This trend is noted through the use of MAN analysis data presented in 2007,

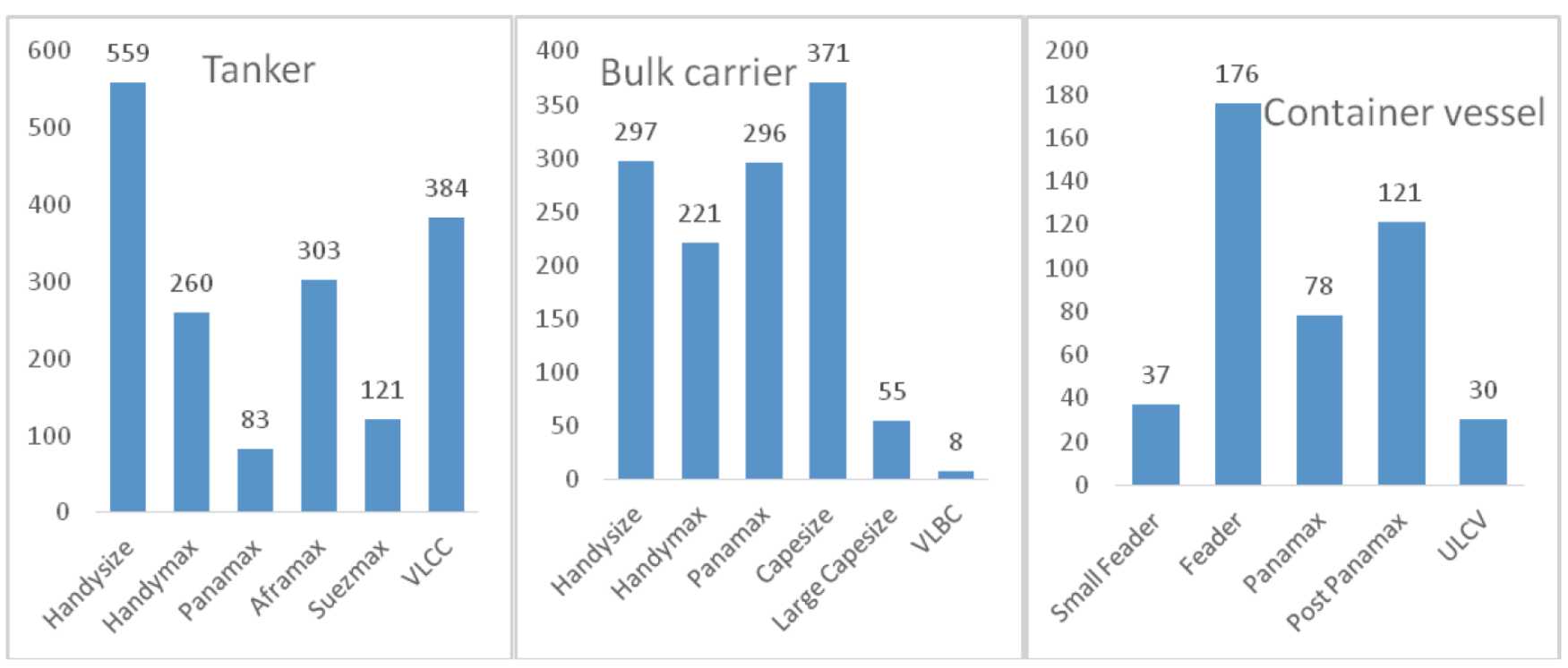

Fig. 2. The ship sample sizes used in this research 
Tab. 1. Mean, minimum and maximum values of parameters of tanker sub-types, where : MCR - total engine power, DWT-deadweight, V-speed

\begin{tabular}{|c|c|c|c|c|}
\hline & & $\begin{array}{l}\text { MCR } \\
{[\mathrm{kW}]}\end{array}$ & $\begin{array}{c}\text { DWT } \\
{[\mathrm{t}]}\end{array}$ & $\underset{[\mathrm{knots}]}{\mathrm{V}}$ \\
\hline \multirow{3}{*}{ Handysize } & Mean & 5456 & 16925 & 13.95 \\
\hline & Min & 2301 & 10000 & 10 \\
\hline & Max & 11700 & 26961 & 16.5 \\
\hline \multirow{3}{*}{ Handymax } & Mean & 8447 & 39548 & 14.59 \\
\hline & Min & 5180 & 27000 & 12 \\
\hline & Max & 13365 & 50571 & 16.2 \\
\hline \multirow{3}{*}{ Panamax } & Mean & 11524 & 72293 & 14.87 \\
\hline & Min & 7500 & 56168 & 14 \\
\hline & Max & 13650 & 79905 & 16 \\
\hline \multirow{3}{*}{ Aframax } & Mean & 13100 & 108562 & 14.77 \\
\hline & Min & 10599 & 81305 & 12 \\
\hline & $\operatorname{Max}$ & 16630 & 122018 & 16 \\
\hline \multirow{3}{*}{ Suezmax } & Mean & 17015 & 157529 & 15.06 \\
\hline & Min & 14300 & 146270 & 14 \\
\hline & Max & 19620 & 167282 & 16 \\
\hline \multirow{3}{*}{ VLCC } & Mean & 27174 & 307139 & 15.58 \\
\hline & Min & 20800 & 279989 & 13 \\
\hline & Max & 33627 & 323182 & 17.4 \\
\hline
\end{tabular}

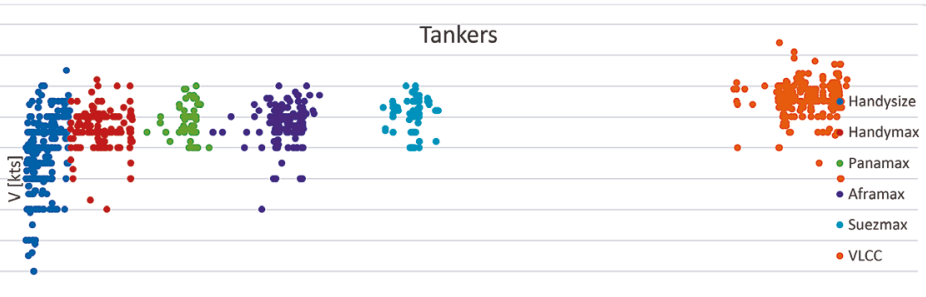

DWT [t]

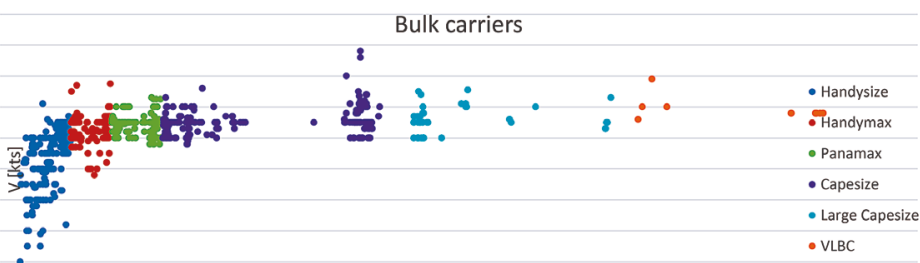

TEU

Container vessels

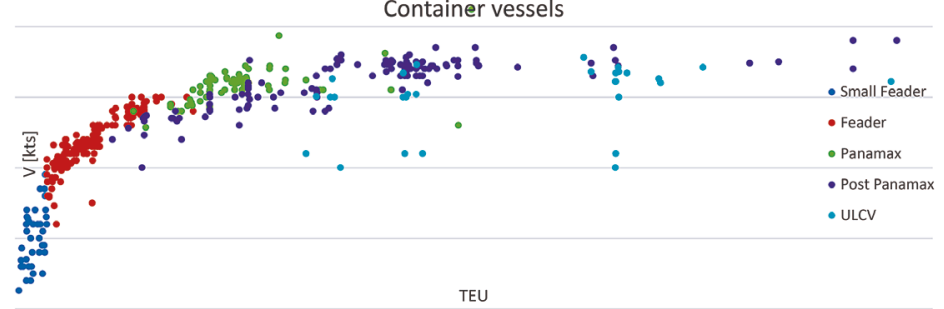

Fig. 3. Ship data used in this research
Tab. 2. Mean, minimum and maximum values of parameters of bulk carrier sub-types, where: MCR - total engine power, DWT-deadweight, V-speed

\begin{tabular}{|c|c|c|c|c|}
\hline & & $\begin{array}{l}\text { MCR } \\
{[\mathrm{kW}]}\end{array}$ & $\begin{array}{c}\text { DWT } \\
{[\mathrm{t}]}\end{array}$ & $\underset{[\mathrm{knots}]}{\mathrm{V}}$ \\
\hline \multirow{3}{*}{ Handysize } & Mean & 5765 & 26378 & 13.53 \\
\hline & Min & 2400 & 10034 & 10 \\
\hline & Max & 9488 & 34961 & 15.1 \\
\hline \multirow{3}{*}{ Handymax } & Mean & 7854 & 44071 & 14.28 \\
\hline & Min & 5640 & 35009 & 12.8 \\
\hline & Max & 9960 & 55000 & 15.75 \\
\hline \multirow{3}{*}{ Panamax } & Mean & 9447 & 65329 & 14.44 \\
\hline & Min & 6780 & 55060 & 13.8 \\
\hline & $\operatorname{Max}$ & 14350 & 79964 & 15.3 \\
\hline \multirow{3}{*}{ Capesize } & Mean & 13896 & 123488 & 14.47 \\
\hline & Min & 8740 & 80013 & 13.8 \\
\hline & Max & 21840 & 186300 & 16.8 \\
\hline \multirow{3}{*}{ Large Capesize } & Mean & 19355 & 226242 & 14.59 \\
\hline & Min & 16040 & 203024 & 14 \\
\hline & Max & 28260 & 299688 & 15.55 \\
\hline \multirow{3}{*}{ VLBC } & Mean & 28500 & 353398 & 14.99 \\
\hline & Min & 25200 & 313049 & 14.6 \\
\hline & Max & 31640 & 403627 & 15.9 \\
\hline
\end{tabular}

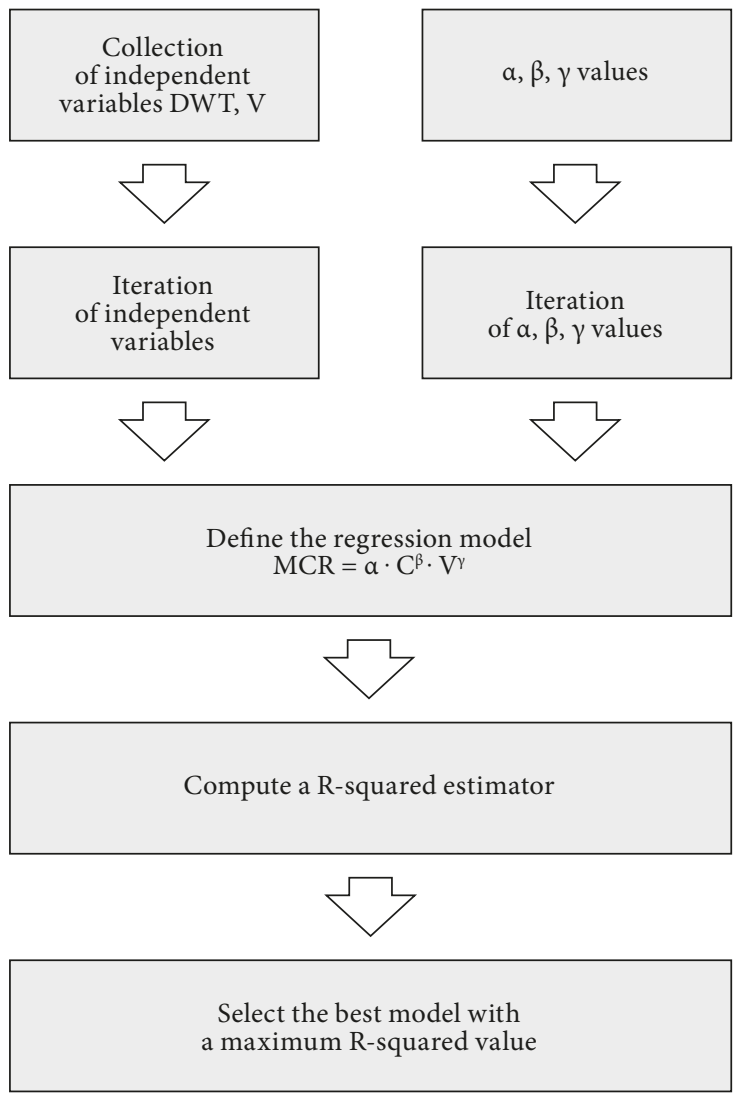

Fig. 4. A general algorithm scheme, where: MCR is main engine total power, $C-D W T$ or TEU capacity, $V$-speed, $\alpha, \beta, \gamma$ are coefficients 
Tab. 3. Mean, minimum and maximum values of parameters of container carrier sub-types, where: MCR - total engine power, DWT-deadweight, $V$ - speed

\begin{tabular}{|c|c|c|c|c|}
\hline & & $\begin{array}{l}\text { MCR } \\
{[\mathrm{kW}]}\end{array}$ & TEU & $\underset{[\mathrm{knots}]}{\mathrm{V}}$ \\
\hline \multirow{3}{*}{ Small Feeder } & Mean & 2764 & 424 & 13.04 \\
\hline & Min & 894 & 90 & 9.30 \\
\hline & $\operatorname{Max}$ & 4400 & 698 & 17.50 \\
\hline \multirow{3}{*}{ Feeder } & Mean & 14357 & 1649 & 19.69 \\
\hline & Min & 6930 & 704 & 14.00 \\
\hline & Max & 28887 & 3889 & 23.00 \\
\hline \multirow{3}{*}{ Panamax } & Mean & 38616 & 4889 & 23.80 \\
\hline & Min & 21735 & 2588 & 20.85 \\
\hline & Max & 68640 & 9954 & 29.20 \\
\hline \multirow{3}{*}{ Post Panamax } & Mean & 52942 & 7595 & 24.05 \\
\hline & Min & 19620 & 2127 & 18.00 \\
\hline & $\operatorname{Max}$ & 81254 & 19224 & 27.00 \\
\hline \multirow{3}{*}{ ULCV } & Mean & 65295 & 10944 & 23.03 \\
\hline & Min & 46620 & 6350 & 18.00 \\
\hline & $\operatorname{Max}$ & 80905 & 19100 & 25.80 \\
\hline
\end{tabular}

2008 and 2010. But Aframax tankers and VLBC container ships are an exception from this apparent rule.

Fig. 3 shows the design speed V against DWT and TEU capacity for tanker, bulk carrier and container ships, which is used in this study.

\section{RESEARCH METHOD}

Nonlinear regression analysis was applied to estimate any relationship between main engine total power, deadweight or TEU capacity and design speed. The following general regression model was assumed in this work:

$$
\operatorname{MCR}=\alpha \cdot C^{\beta} \cdot V^{\gamma}
$$

where:

MCR - main engine total power,

C - DWT or TEU capacity,

$\mathrm{V}-$ design speed,

$\alpha, \beta, \gamma$-regression model coefficients.

An ordinary least square approach was used in the presented regression analysis.

On the basis of the method this Author developed an algorithm to find $\alpha, \beta, \gamma$ values. The values of $\alpha, \beta, \gamma$ were iteratively searched through all their possible combinations by using this algorithm. The general algorithm scheme is shown in Fig. 4.

NdCurveMaster software (Version 3.1, SigmaLab, 2017) was used to develop regression equations presented in this paper. The regressions containing the calculated values of $\alpha, \beta, \gamma$ coefficients for the estimation of engine total power are presented in the next part of the article.
Tab. 4. Values of the regression coefficients $(\alpha, \beta, \gamma)$, standard deviation $S E$ and R-square error relating to the model (4) for tankers

\begin{tabular}{|c|c|c|c|c|c|}
\hline Tanker type & $\alpha$ & $\beta$ & $\gamma$ & $\begin{array}{c}\text { SE } \\
{[\mathrm{kW}]}\end{array}$ & $\begin{array}{c}\text { R-square } \\
\text { error }\end{array}$ \\
\hline All tanker types & 2.66 & 0.6 & 0.6 & 1662 & 0.988 \\
\hline All tanker types & \multicolumn{3}{|c|}{ Piko (1980) } & 2044 & 0.983 \\
\hline All tanker types & \multicolumn{2}{|c|}{ Żelazny (2015) } & 1738 & 0.988 \\
\hline Handysize & 0.364 & $1 / 2$ & 1.8 & 868 & 0.974 \\
\hline Handymax & 17.033 & $1 / 3$ & 1 & 1285 & 0.977 \\
\hline Panamax & 0.1 & 0.8 & 1 & 1134 & 0.990 \\
\hline Aframax & 18.59 & $1 / 3$ & 1 & 1332 & 0.989 \\
\hline Suezmax & 2.894 & $1 / 2$ & 1 & 1180 & 0.995 \\
\hline VLCC & $3.2 \mathrm{E}-06$ & $1 / 7$ & $1 / 2$ & 1922 & 0.995 \\
\hline
\end{tabular}

\section{RESULTS}

The following models were fitted to ship data:

- for tankers and bulk carriers:

$$
\mathrm{MCR}=\alpha \cdot \mathrm{DWT}^{\beta} \cdot \mathrm{V}^{\gamma}
$$

- for container ships:

$$
\mathrm{MCR}=\alpha \cdot \mathrm{TEU}^{\beta} \cdot \mathrm{V}^{\gamma}
$$

where:

MCR - main engine total power [kW],

DWT - deadweight capacity [t],

TEU - number of containers [-],

$\alpha, \beta, \gamma$ - regression model coefficients,

$\mathrm{V}$ - design speed [knots].

Regression coefficient values $(\alpha, \beta, \gamma)$, standard (SE) and the $\mathrm{R}$-squared errors relating to the worked-out regressions (4) and (5) for each ship type are given in Tab. 4, 5, 6. The tables also show the standard deviations SE and the R-squared errors relating to the methods of Piko and Żelazny with regard to the Sea-web Ships database. Fig. 5-8 show the relationship between deadweight, number of containers, speed and main engine total power for each ship type, calculated by using the regressions (4) and (5).

Fig. 5 shows the total power plotted against deadweight and TEU capacity for each ship type by using the methods of Żelazny and Piko. In Żelazny's regressions the waterline area AWL and speed V are taken into account as follows:

$$
\begin{aligned}
& \mathrm{MCR}_{\mathrm{T}}=\left(7 \mathrm{E}-07 \cdot \mathrm{A}_{\mathrm{wL}}{ }^{2}+0.1737 \cdot \mathrm{A}_{\mathrm{wL}}+321.58\right) \cdot \mathrm{V} \\
& \mathrm{MCR}_{\mathrm{C}}=\left(7 \mathrm{E}-07 \cdot \mathrm{A}_{\mathrm{wL}}{ }^{2}+0.1737 \cdot \mathrm{A}_{\mathrm{WL}}+321.58\right) \cdot \stackrel{\mathrm{V}}{(7)} \\
& \mathrm{MCR}_{\mathrm{B}}=\left(7 \mathrm{E}-07 \cdot \mathrm{A}_{\mathrm{wL}}{ }^{2}+0.1737 \cdot \mathrm{A}_{\mathrm{wL}}+321.58\right) \cdot \stackrel{\mathrm{V}}{ }
\end{aligned}
$$

where:

$\mathrm{MCR}_{\mathrm{T}}$ - tanker main engine total power $[\mathrm{kW}]$,

$\mathrm{MCR}_{\mathrm{C}}$ - container ship main engine total power [kW],

$\mathrm{MCR}_{\mathrm{B}}$ - bulk carrier main engine total power [kW],

$\mathrm{A}_{\mathrm{wL}}$ - waterline area $\left[\mathrm{m}^{2}\right]$,

$\mathrm{V}$ - speed $[\mathrm{m} / \mathrm{s}]$. 
Tab. 5. Values of the regression coefficients $(\alpha, \beta, \gamma)$, standard deviation $S E$ and R-square error relating to the model (4) for bulk carriers

\begin{tabular}{|c|c|c|c|c|c|}
\hline Bulk carrier type & $\alpha$ & $\beta$ & $\gamma$ & $\begin{array}{c}\text { SE } \\
{[\mathrm{kW}]}\end{array}$ & $\begin{array}{c}\text { R-square } \\
\text { error }\end{array}$ \\
\hline $\begin{array}{c}\text { All bulk carrier } \\
\text { types }\end{array}$ & 4.297 & 0.6 & 0.4 & 1167 & 0.989 \\
\hline $\begin{array}{c}\text { All bulk carrier } \\
\text { types }\end{array}$ & \multicolumn{2}{|c|}{ Piko (1980) } & 2202 & 0.964 \\
\hline $\begin{array}{c}\text { All bulk carrier } \\
\text { types }\end{array}$ & \multicolumn{2}{|c|}{ Żelazny (2015) } & 1363 & 0.986 \\
\hline \begin{tabular}{c} 
Handysize \\
\hline $\begin{array}{c}\text { Handymax } \\
\text { Panamax }\end{array}$
\end{tabular} $0^{0.731}$ & 0.691 & 0.6 & 1.1 & 785 & 0.990 \\
\hline Papesize & 0.858 & 0.6 & 1 & 1267 & 0.992 \\
\hline Large Capesize & $1.81 \mathrm{E}-02$ & 0.8 & 1.5 & 1788 & 0.991 \\
\hline VLCC & $1.58 \mathrm{E}-03$ & 0.8 & 2.4 & 1041 & 0.998 \\
\hline
\end{tabular}

In order to compare the engine power calculated by the Żelazny method to the regressions (4) and (5), the relationship between the DWT or TEU capacity and waterline area AWL were determined as follows:

for tankers:

$$
\mathrm{A}_{\mathrm{WL}}=-617.39+9.158 \cdot \mathrm{DWT}^{0.6}
$$

for bulk carriers:

$$
\mathrm{A}_{\mathrm{WL}}=1497.6+0.658 \cdot \mathrm{DWT}^{0.8}
$$

for container ships:

$$
\mathrm{A}_{\mathrm{wL}}=-5412.3+1003.1 \cdot \mathrm{TEU}^{0.3} .
$$

Fig.9 shows the relationship between the DWT or TEU capacity and waterline area AWL calculated by using the equations (9) (11). The values of the standard deviation SE and the R-squared error relating to the equations are given in Tab. 7 .

\section{DISCUSSION OF RESULTS}

The correlation between coefficients presented in Tab. 4, 5, 6 was high due to the use of a regression model with no intercept term. When a regression without any constant in the model is used it can lead to an unnatural increase in a sum of squares (residual and total) and an increase in R-square error values. Therefore, in this case the standard deviation SE may be a more reliable estimator.

Tab. 4,5,6 show the accuracy of the worked - out regressions for all types of ships than when compared to the SeaWeb database, which was higher than for the equations published by Piko and Zelazny. Though it should be noted that the accuracy of Piko regression was the lowest.

Żelazny equations that were developed (2015) for tankers and bulk carriers are reasonably accurate.
Tab. 6. Values of the regression coefficients $(\alpha, \beta, \gamma)$, standard deviation $S E$ and $R$-square error relating to the model (5) for container ships

\begin{tabular}{|c|c|c|c|c|c|}
\hline $\begin{array}{c}\text { Container ship } \\
\text { type }\end{array}$ & $\alpha$ & $\beta$ & $\gamma$ & $\begin{array}{c}\text { SE } \\
{[\mathrm{kW}]}\end{array}$ & $\begin{array}{c}\text { R-square } \\
\text { error }\end{array}$ \\
\hline $\begin{array}{c}\text { All container ship } \\
\text { types }\end{array}$ & 10.13 & 0.6 & 1 & 4210 & 0.987 \\
\hline $\begin{array}{c}\text { All container ship } \\
\text { types }\end{array}$ & \multicolumn{3}{|c|}{ Piko (1980) } & 7673 & 0.959 \\
\hline $\begin{array}{c}\text { All container ship } \\
\text { types }\end{array}$ & \multicolumn{2}{|c|}{ Zelazny $(2015)$} & 7104 & 0.965 \\
\hline $\begin{array}{c}\text { Small Feeder } \\
\text { Feeder }\end{array}$ & 11.634 & 0.8 & $1 / 4$ & 215 & 0.995 \\
\hline Panamax & 8.885 & 0.8 & $1 / 2$ & 2183 & 0.997 \\
\hline Post Panamax & 25.593 & $1 / 2$ & 1 & 4397 & 0.993 \\
\hline ULCV & 560.695 & 0.4 & $1 / 3$ & 3317 & 0.999 \\
\hline
\end{tabular}

Tab. 7. The values of the standard deviation SE and the R-square error relating to the worked-out regressions (9), (10), (11)

\begin{tabular}{|c|c|c|}
\hline Equation number & $\mathrm{SE}\left[\mathrm{m}^{2}\right]$ & R-square \\
\hline$(9)$ & 308 & 0.995 \\
\hline$(10)$ & 376 & 0.983 \\
\hline$(11)$ & 656 & 0.949 \\
\hline
\end{tabular}

However, the author's equations developed for container ship power resulted in the halving of the power estimates in standard deviation SE, compared to the Piko and Zelazny regressions.

Tab. 4, 5, 6 show that the standard deviation for the estimation of ship engine total power for tankers, bulk carriers and container ships is generally higher than that for the estimation of the engine power of their sub-types.

The exception are the regressions for VLCC tankers, Capesize, Large Capesize and VLBC bulk carriers and Post Panamax container ships. The engine power estimate standard deviation for these ships' sub-types is higher than that for the main ship types. As Tab. 1, 2, 3 show, this high value of standard deviation results from a much higher value of engine power range in case of the ships' sub-types. In addition, correlation coefficient values for the estimate of engine power of sub-types' ship are much higher than the correlation coefficient for the estimate of engine power of tanker, bulk carrier and container ship. This means that the accuracy of engine power estimation equations for ship sub-types is higher than for other main types.

An analysis of Tab. 4-6 and Fig. 5-8 shows that the effect of DWT and TEU capacity on main engine power is non-linear.

In the equations (4) and (5) the power exponent coefficient $\beta$ reaches values lower than 1 . However, the tables and figures in question show that the speed has a linear (or almost linear) effect on total engine power. The exponential coefficient $\gamma$ takes values from 1 to 1.1 in the equations (4) and (5). 

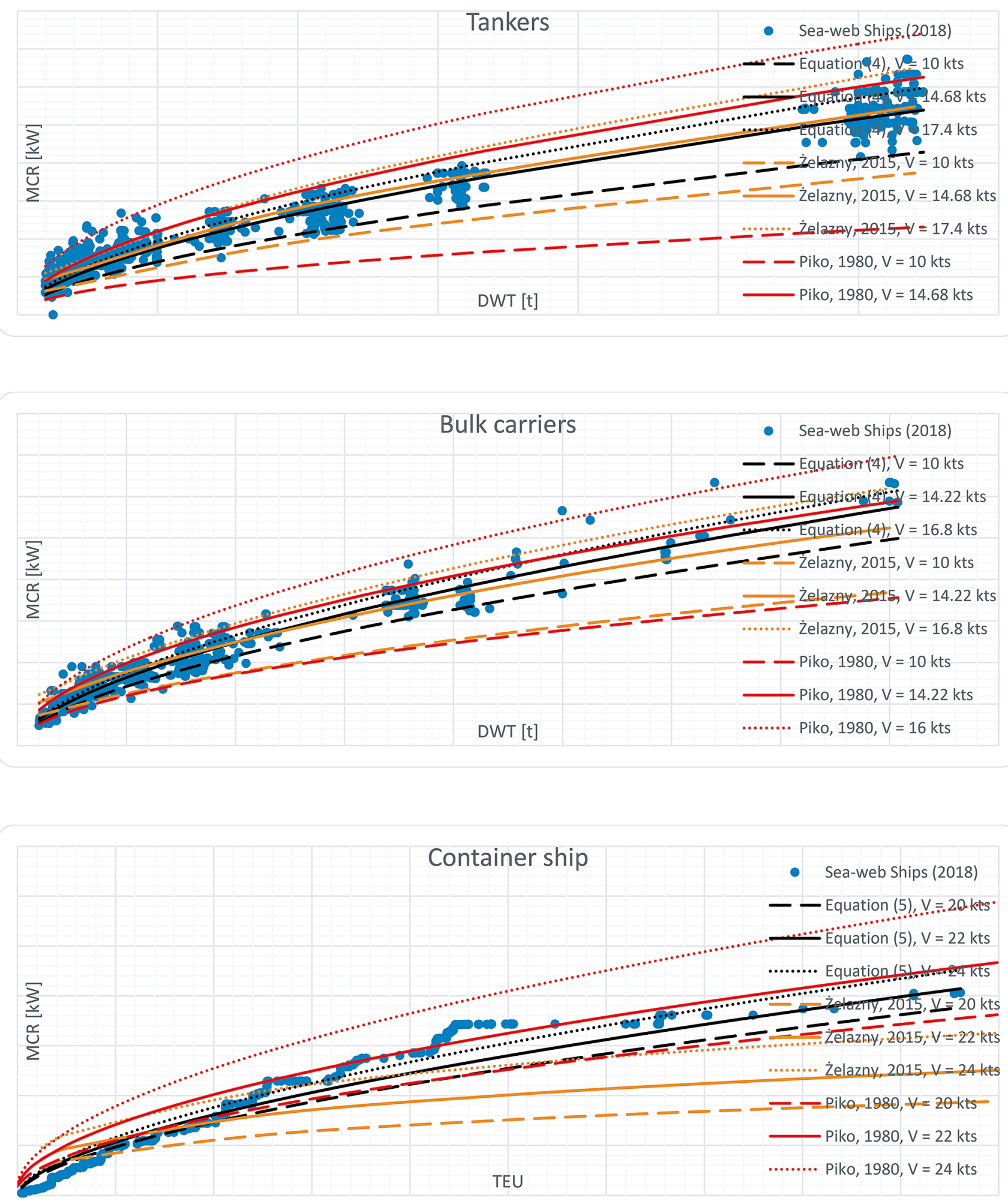

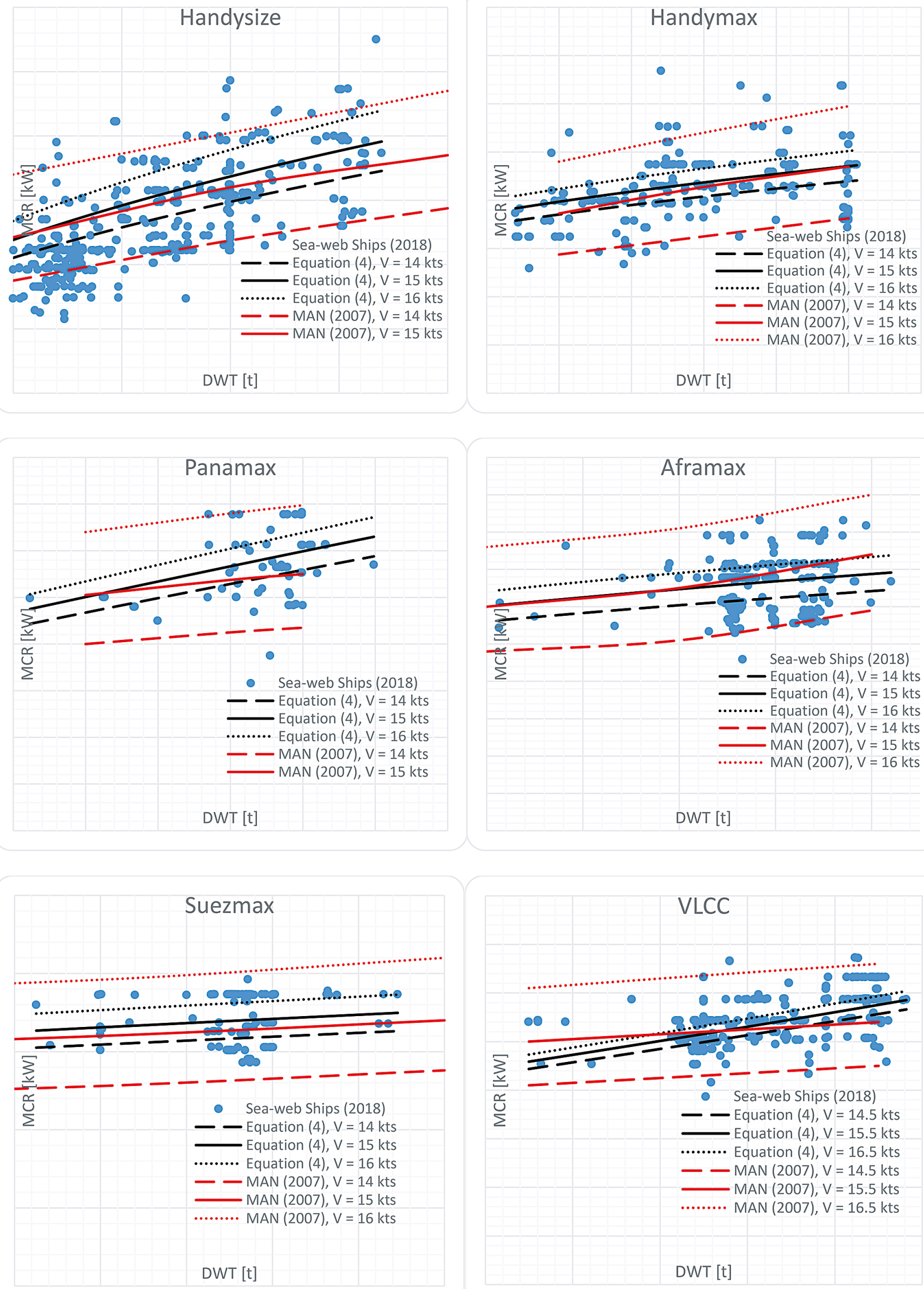

Fig. 6. The main engine total power MCR in function of DWT capacity, for tankers 


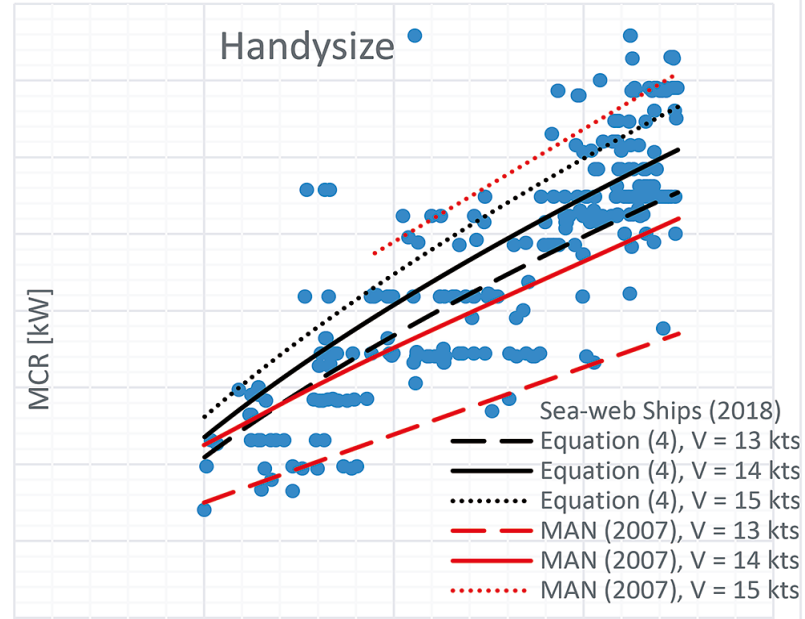

DWT $[\mathrm{t}]$
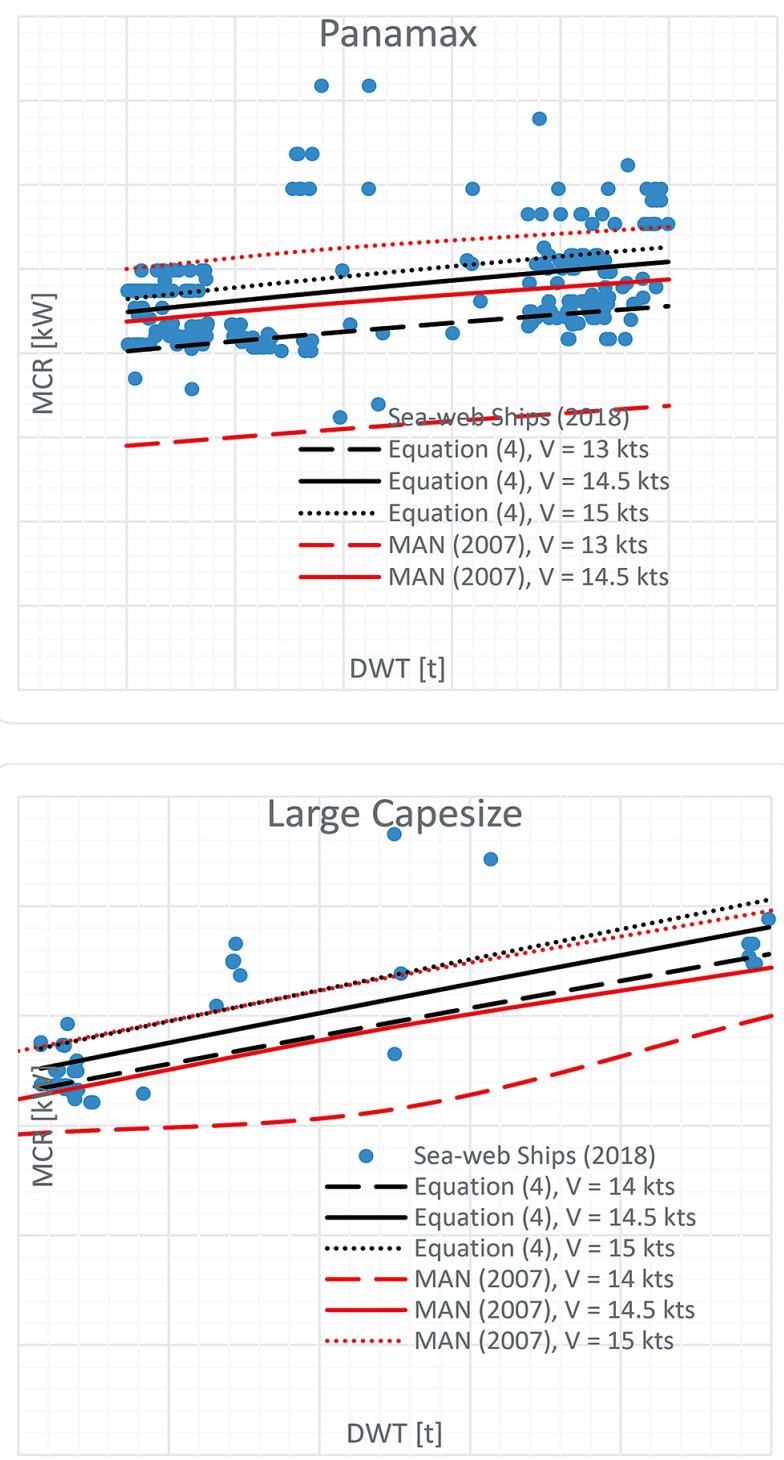
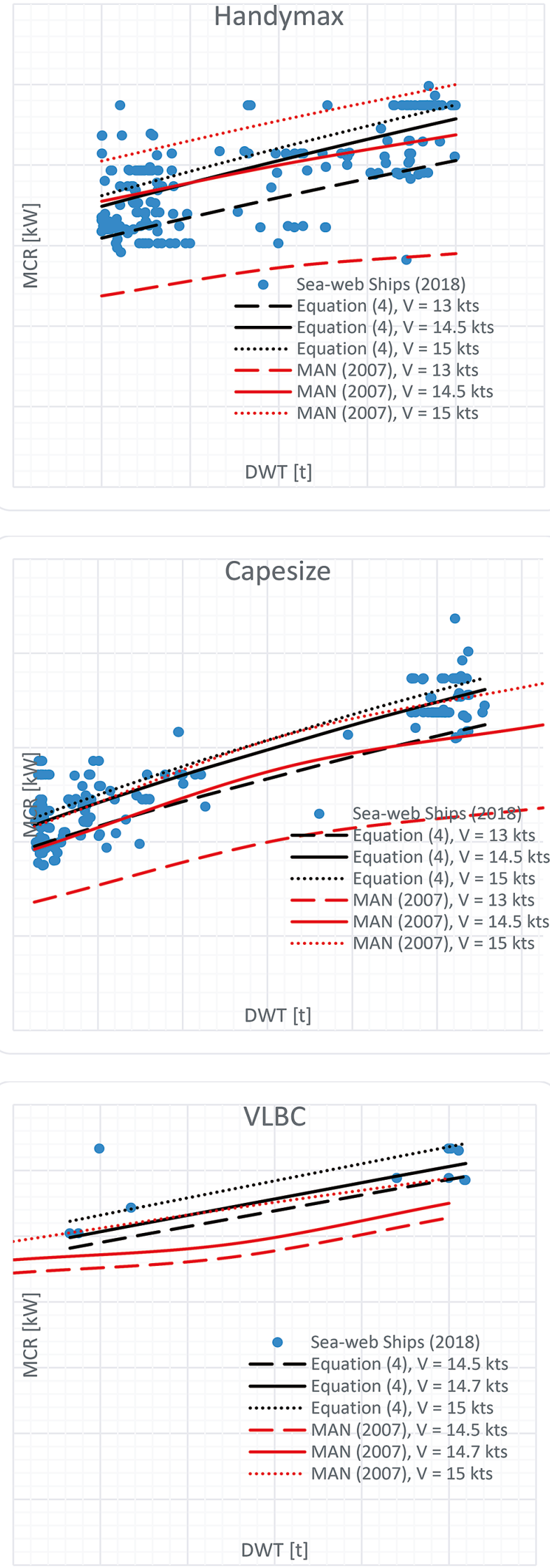

Fig. 7. The main engine total power MCR in function of DWT capacity, for bulk carriers 

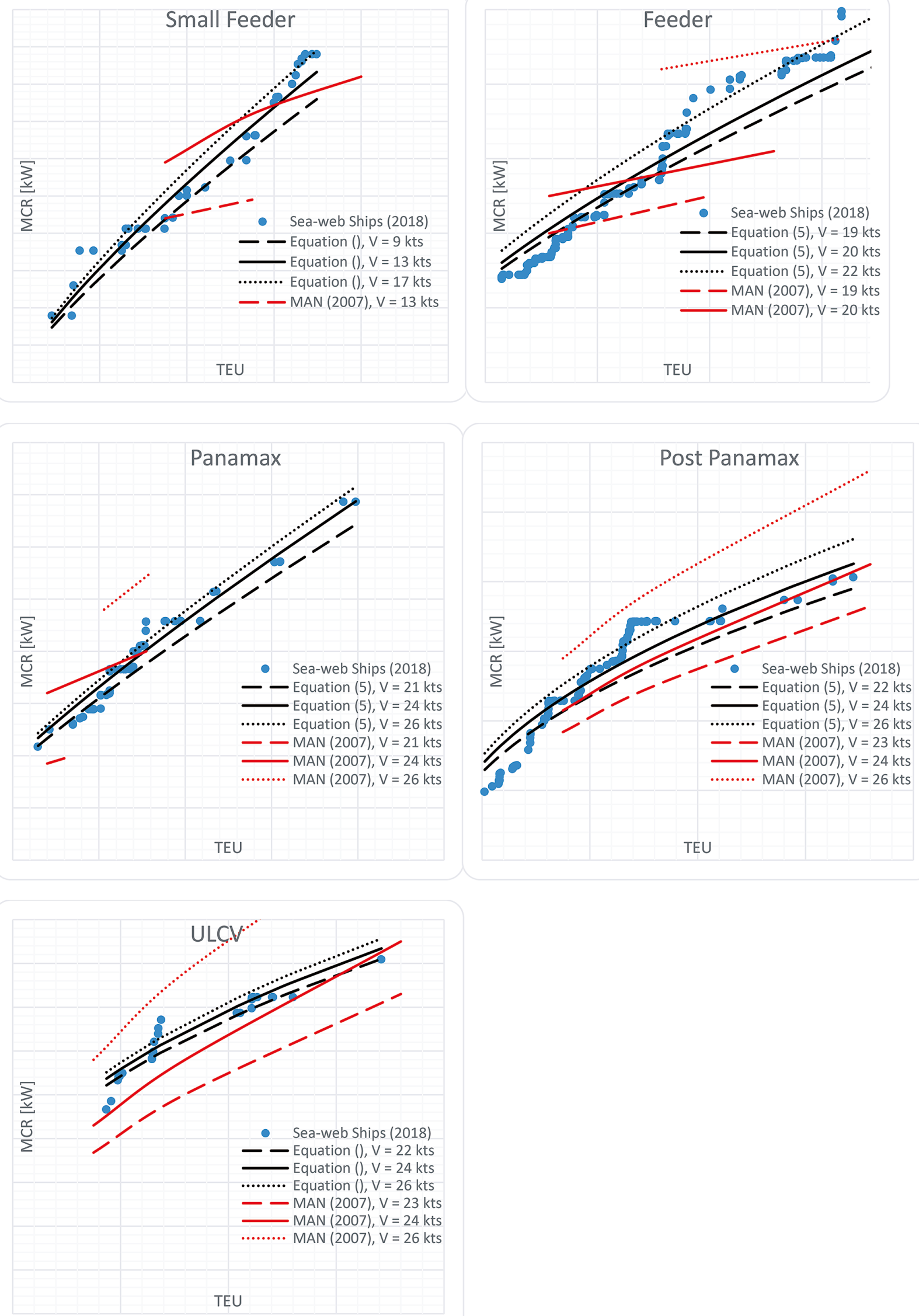

Fig. 8. The main engine total power MCR in function of TU capacity, for container ships 


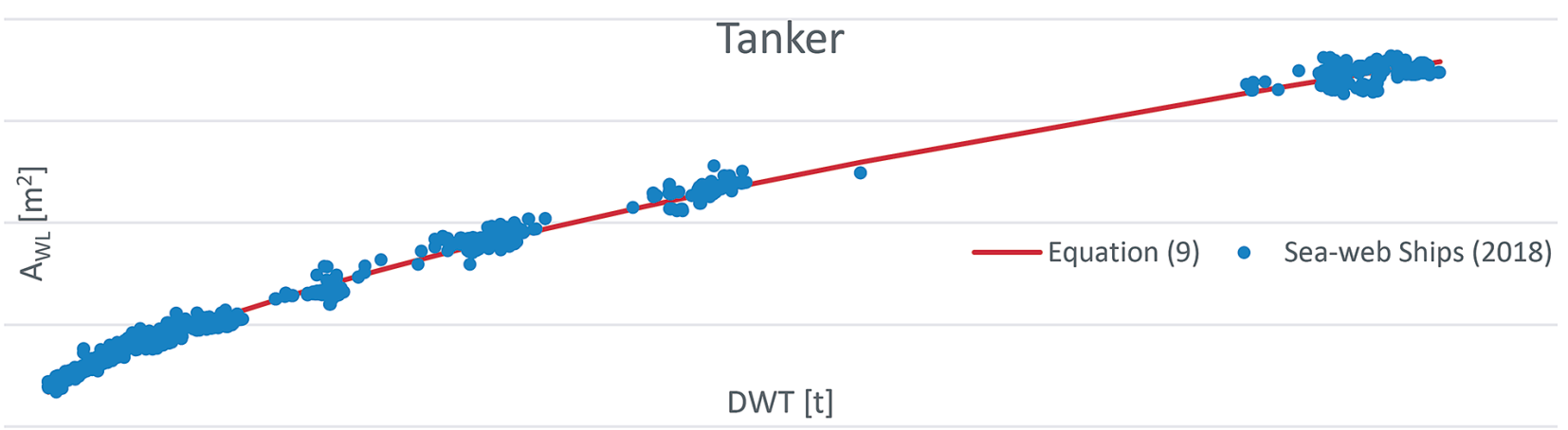

\section{Bulk carrier}
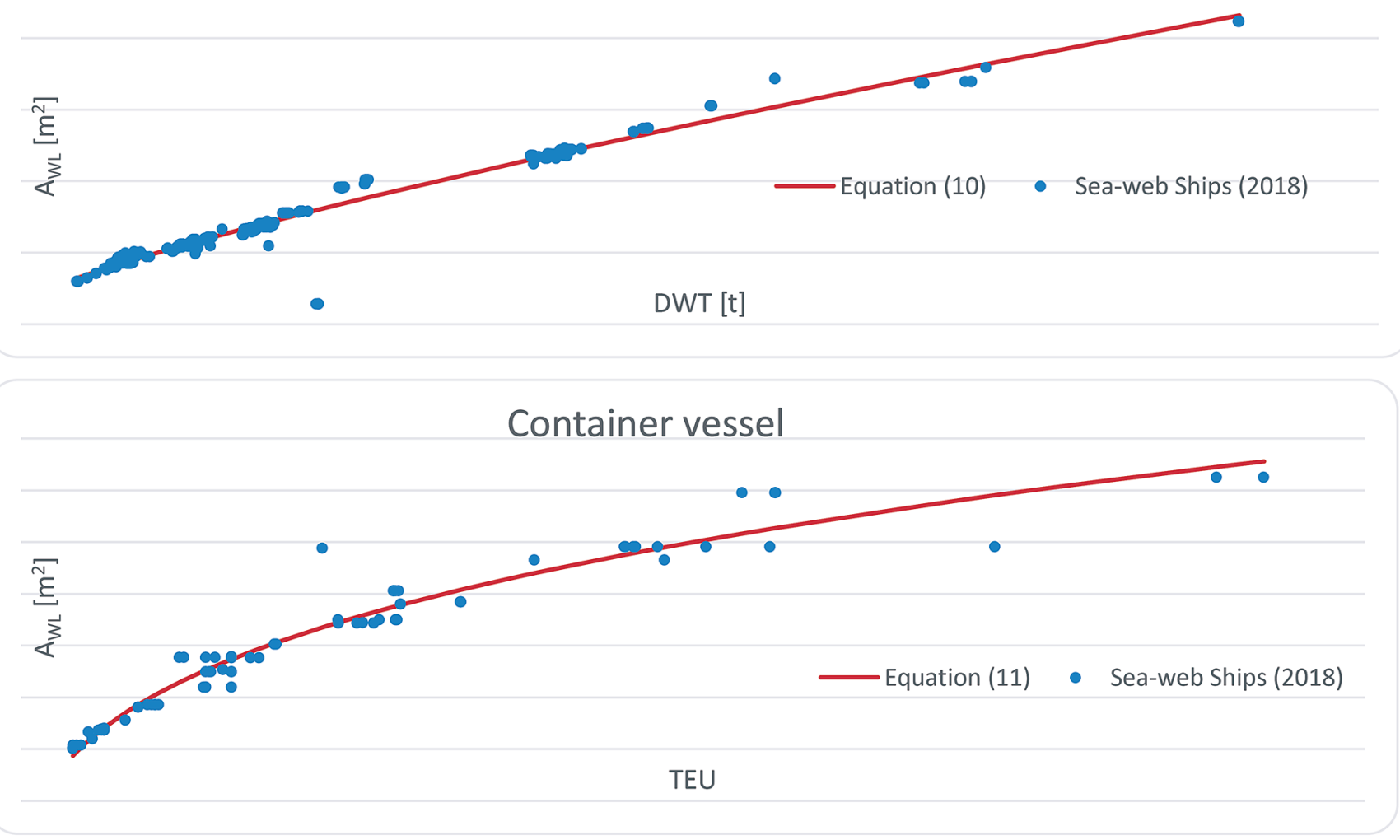

Fig. 9. The waterline area AWL in function of DWT or TEU capacity

But for some sub-types, the speed has a clearly nonlinear effect on engine power. The exponential coefficient $\gamma$ reaches the value of 1.8 for Handysize tankers and the value of 2.4 for VLBC bulk carriers. In contrast, the speed of VLCC tankers, Small Feeder, Panamax and ULCV container ships has a smaller influence on each individual engine power than in case of the other ship types.

Fig. 5 shows that the worked-out regressions (4) and (5) are generally well matched to SeaWeb data. However, the regressions developed by Piko and Żelazny are worse matched to the reference data. Significant inaccuracies occur in extreme speed values in case of using the Piko and Żelazny methods. These regressions erroneously assess the influence of speed on engine power; Żelazny regressions applied to container ships appeared the least accurate. Low accuracy of Pico equation may result from an out-of-date ship database that was used for developing the regressions.

Fig. 6-8 compare regressions used with the SeaWeb data and MAN nominal diagrams. The figures show that the MAN nominal diagrams are well matched to SeaWeb data only in the case of average speed values. For extreme speeds, power estimated by using MAN diagrams significantly exceeds the ship power values in the SeaWeb database. In particular, speed values which are lower than the given ship sub-type average speed mean that the estimated power is lower than SeaWeb ship power. Similarly, for ship speed greater than the average speed of a given ship type, the estimated power is much greater than the engine power of new- built ships. Perhaps this is due 
to the fact that nominal diagrams do not sufficiently take sea trials tests into account.

The equations presented in this article can be used only in the ranges of deadweight and speed values shown in Tab. 1-3 for each of the ship sub-types. For example, according to Tab. 1, the equation (4) for engine power estimate of Handysize bulk carrier can only be used for:

- fdeadweight - from 10034 to $34961 \mathrm{t}$,

- fspeed - from 10 to 15.1 knots.

The formulas presented in this article estimate total ship engine power depending on two independent variables simultaneously: DWT or TEU capacity and speed. However, it is possible to transform the formulas into a simpler form based on one independent variable, i.e. either deadweight capacity, TEU capacity or speed. To do this, the regression coefficients presented in Tab. 4-6 should be converted by using average values shown in Tab. 1-3. For example, the equation (4) can be transformed to a simpler form by using:

- fthe average value of Handysize bulk carrier speed V $=13.53$ knots, as follows:

$\mathrm{MCR}=0.731 \cdot \mathrm{DWT}^{0.6} \cdot 13.53^{1.1}=12.833 \cdot \mathrm{DWT}^{0.6}$

- or the average value of Handysize bulk carrier deadweight $\mathrm{DWT}=26,378 \mathrm{t}$, as follows:

$$
\mathrm{MCR}=0.731 \cdot 26378^{0.6} \cdot \mathrm{V}^{1.1}=328.6 \cdot \mathrm{V}^{0.6}
$$

It is important to remember that the simplification of the equation (4) to the equation (12) or (13) reduces its accuracy.

\section{CONCLUSIONS}

This article presents a set of simple regression functions for the estimation of total engine power of tankers, bulk carriers and container ships depending on deadweight or TEU capacity and speed, for new-built ship sub-types. The article also presents total power estimation equations for ship sub-types.

The relationships between engine total power, DWT or TEU capacity and speed presented in the article offer similar trends that can be found in relationships presented by Piko (1980), Żelazny (2015) and MAN. The comparisons presented in this study clearly show that the regression formulas by Piko , Żelazny and MAN are accurate for the design of modern ships only in the case of medium-size ships. In the speed range of remaining ships, estimated engine power values obtained with the use of the methods by Piko, Żelazny and MAN incorrectly match new-built ship characteristics.

Accuracy of the regressions developed in this article for full ship capacity range is higher than in the case of the corresponding Piko and Żelazny regressions.

The nominal engine power diagrams presented by MAN are often used for ship engine power estimates in ship design practice. This study shows that using the nominal diagrams for engine power estimates for extreme speed values (in relation to the average speed value) may result in inaccurate estimations and lead to design errors.

For a ship speed much lower or higher than the average speed of a given ship type, estimated engine power may be incorrect, and this would lead to over- or under- estimated propulsion mass, mass of stores and ship building costs. The analyses presented in this article show that the accuracy of regressions worked-out by this author is higher, over full design speed range of ship sub-types, than that resulted from MAN diagrams in regard to the ships' statistical data published in the Sea-web database.

The analyzes show that the regressions developed for tanker, bulk carrier and container ship sub-types are characterized by a higher accuracy than the regressions developed for their main types. The regressions represent an improvement over other modern preliminary design methods.

All equations presented in this paper refer to the most contemporary ships and may find practical application at the preliminary ship design stage and contribute to ship design theory development.

The research confirms that DWT and TEU capacity has a non-linear effect on total engine power. However, speed of tanker, bulk carrier and container ships, correlated with DWT and TEU capacity, usually affects total engine power in a linear way.

\section{REFERENCES}

1. Celik F., Erturk I, Turan E.: Investigation of main particulars subject to minimum building cost for chemical tankers. Ocean Engineering 73 (2013), pp. 32-37.

2. Chądzyński W.: Elements of contemporary design methods offloating objects (in Polish). Scientific Reports of Szczecin University of Technology (2001), Department of Ocean Engineering and Marine System Design.

3. Ekincia S., Celebia U.B., Bala M., Amasyalia M.F., Boyacia K.: Predictions of oil/chemical tanker main design parameters using computational intelligence techniques. Applied Soft Computing 11 (2011), pp. 2356-2366.

4. Elvekrok D.R.: Concurrent Engineering in Ship Design. Journal of Ship Production, (1997) Vol. 13, No. 4, pp. 258-269.

5. Sea-web Ships (2018) [Online]. Available from: https:// maritime.ihs.com [Accessed: 10. Feb. 2018]

6. Kristensen H.O.: Determination of Regression Formulas for Main Dimensions of Tankers and Bulk Carriers based on IHS Fairplay data. Project no. 2010-56, Emissionsbeslutningsstøttesystem. Work Package 2, Report No. 02. (2012), Technical University of Denmark.

7. Lin C., Shaw H.: Feature-based estimation of preliminary costs in shipbuilding. Ocean Engineering 144 (2017), pp. 305-319. 
9. Papanikolaou A.: Ship Design: Methodologies of Preliminary Design. Springer, Dordrecht (2014).

10. Piko G. P.: Regression Analysis of Ship Characteristics. C. J. Thompson Commonwealth Government Printer, Canberra (1980).

11. Rawson K.J. and Tupper E.C.: Basic Ship Theory. Ship Dynamics and Design. Volume 2. Fifth edition. ButterworthHeinemann, (2001).

12. Schneekluth H., Bertram V.: Ship Design for Efficiency and Economy. Second edition. Butterworth-Heinemann, (1998).

13. SigmaLab (2017) ndCurveMaster [Computer software] Available from: www.ndcurvemaster.com [Accessed: 4 Dec. 2017]. Szczecin, Poland.

14. Watson D.G.M.: Practical Ship Design. Volume 1. Elsevier Science, (1998).

15. Żelazny K.: Method for determination of service speed useful in the initial design of cargo vessels under statistical weather conditions occurring on shipping route (in Polish). West Pomeranian University of Technology, Publishing House, Szczecin, (2015).

\section{Tomasz Cepowski}

e-mail:t.cepowski@am.szczecin.pl

Maritime University of Szczecin ul. W. Chrobrego 1-2

70-500 Szczecin

Poland 